\title{
Expression of Defense Responses in Tomato against Vascular Wilt and Fruit Borer through Consortia of Fluorescent Pseudomonads and Entomopathogenic Fungi
}

\author{
P. Lakshmidevi ${ }^{*}$, S. Parthasarathy ${ }^{1}$, C. Gopalakrishnan ${ }^{1}$, \\ G. Karthikeyan ${ }^{2}$, S. Sridharan ${ }^{2}$ and T. Saraswathi ${ }^{3}$ \\ ${ }^{1}$ Department of Plant Pathology, ${ }^{2}$ Department of Agricultural Entomology, Centre for Plant \\ Protection Studies, Tamil Nadu Agricultural University, Coimbatore-641003, India \\ ${ }^{3}$ Department of Vegetable Crops, Horticultural College and Research Institute, Tamil Nadu \\ Agricultural University, Coimbatore-641003, India \\ *Corresponding author
}

\section{A B S T R A C T}

\section{Keywords}

Biological control, Fusarium wilt, Helicoverpaarmigera, Pseudomonas fluorescens, Tomato.

Article Info

Accepted:

24 September 2017 Available Online: 10 November 2017
Tomato (Solanum lycopersicum L.) is a major contributor to the fruit vegetable diet of humans. It is cultivated in essentially all countries either in fields or in protected culture. Tomato crop is affected by various pest and diseases. Among the diseases, Helicoverpa fruit borer and Fusarium vascular wilt is regarded as the most devastating to tomato around the world. The biological control method has been considered as a promising approach for the management of pest and diseases by enhancing the inherent systemic resistance. However the most of the approaches mainly biological control of pest and disease have used a single organism. This accounts for inconsistency in the antagonistic activity of biocontrol agent. So the combinatorial application of biocontrol agents could be viable for the management major pests and diseases in crop plants. In our study, both Pseudomonas fluorescens and Beauvaria bassiana possess excellent antagonistic activity against $F$. oxysporum f.sp. lycopersici and $H$. armigera respectively under in vitro. Combinatorial application of $P$. fluorescens and $B$. bassiana was found to reduce the pest and pathogen in tomato crop under glass house condition. Also, which imparts innate immune response by the production of defence related enzymes viz., peroxidase, polyphenol oxidase, superoxide dismutase and catalase on the treated host against necrotrophic pathogen and herbivore. The native polyacrylamide gel electrophoresis (PAGE) experiment showed that one to four isoforms of the defense related enzymes each with greater intensity were expressed in the given treatments. This is indicating that the restriction of insect pest and pathogens in tomato plants was mainly due to application of

\section{Introduction}

Tomato (Lycopersicon esculentum L. Krust) is considered as one of the most important and remunerative vegetable crop cultivated throughout the world owing to its high nutritive value as well as its antioxidant and curative properties. Fusarium wilt caused by Fusarium oxysporumf.sp. lycopersici (Sacc) (Abdel-Monaim, 2012), and Fruit borer Helicoverpa armigera is a major yield limiting factors of tomato in India 
(Prabhukarthikeyan et al., 2013). The management of the pest and disease can be done through cultural, chemical, physical, biological control and use of resistant varieties. But most of the conventional chemical, biological and use of resistant varieties tend towards the direct control of the biotic hazards by their elimination. Sometimes, these practices raise problem due to development of resistant strains of the pest and pathogen which may become very tedious to control. To overcome these problems, search for new areas for managing the pests are explored. One of the best strategies developed to manage various biotic threats is induced resistance. It has been found that pre application of tomato seedling with bio agents, plant extracts, avirulent races of pathogens, organic amendments and some inorganic chemical provided the systemic induced resistance in various crops (Kuc, 1987). Biochemical and physiological changes associated with induction of resistance are due to the response to inducing agents which are in the form like phytoalexins, lignin, callose and plant pathogenesis and defence related proteins (van Loon et al., 1998).

Chemical control of pest and diseases is usually expensive and may have a negative impact on the environment and on public health. Biological control makes management of pest and diseases less dependent on the use of high risk chemicals and is environmentally friendlyhighly effective throughout the crop growth period with high rhizosphere competency and competitive saprophytic ability (Parthasarathy et al., 2017). Fluorescent Pseudomonads are amongst the most effective biological control agents against soil borne plant pathogens. Several isolates of Pseudomonas fluorescens, $P$. putida, and $P$. aureofaciens suppress the soil borne pathogens through rhizosphere colonization, antibiosis and iron chelation by siderophore production. Certain fluorescent pseudomonads are also found to promote plant growth by production of plant growth promoting substances and thus are called Plant Growth Promoting Rhizobacteria (PGPR). PGPR are known to induce resistance against fungal, bacterial and viral diseases.

Recently, entomopathogenic microorganisms provide an alternative method to reduce the use of synthetic pesticide in integrated pest management in sustainable agriculture (Liu et al., 2002; Al-mazaawi et al., 2006).

Compared to other microorganisms, entomopathogenic fungi are known to infect a broader range of insects including Lepidoptera, Homoptera, Hymenoptera, Coleoptera and Diptera. Among the various entomopathogenic fungi, the deuteromycetous fungi Beauveria bassiana (Balsamo) Vuillemin (Vanitha and Parthasarathy, 2017) has been used extensively for the control of wide range of insect pests and also induce systemic resistance by activating lipoxygenase pathways. It is also known to be a plant growth promoting fungi (PGPF), when applied as consortial mode into soil.

PGPR and PGPF systemically activate the plant's latent defense mechanism against pathogens called Induced Systemic Resistance (ISR) (Narayanan et al., 2016). Recent studies on mechanisms of biological control by PGPR reveal that several strains protect the plants from pest and pathogen attack by enhancing innate immunity and plant growth promotion activities. Meanwhile, strengthening the epidermal and cortical cell walls with deposition of newly formed barriers beyond infection sites including callose, lignin and phenolics and by activating defense genes encoding chitinase, Peroxidase (PO), Phenylalanine ammonialyase (PAL) and Polyphenoloxidase (PPO) (Nandakumar et al., 2001; Parthasarathy et al., 2016). These 
observations led to exploration in the present investigation.

\section{Materials and Methods \\ Collection of pathogen}

F. oxysporum f.sp. lycopersici fungal virulent strain was used in this experiment. The strain was collected from Department of Plant Pathology, Tamil Nadu Agricultural University, Coimbatore. The pathogen was purified and subcultured on the PDA and incubated at room temperature $\left(28 \pm 2^{\circ} \mathrm{C}\right)$ for 7 days. The suspension of conidia was prepared from 7-12 days-old cultures, by inundating the plates with sterile water, vortexing the suspension and filtering through cheese cloth. Then the suspension was adjusted to $10^{-5}$ spores $\mathrm{mL}^{-1}$ using a haemocytometer. After purification of fungi, a slide was prepared from fungal colony and observed under compound microscope.

\section{Collection and mass rearing of insect}

H. armigera larvae were collected from tomato field at the Department of Vegetable Crops, TNAU, Coimbatore and the initial culture was established in laboratory. The larvae were reared on artificial diet in separate plastics vials $(4 \times 4 \times 2)$ due to avoid cannibalism. When larvae transformed into pupae they were shifted into soil filled jars for adult emergence.

The emerged moths were collected, sexed and kept in cylindrical plastic buckets (one male and one female). Paper strips were hung for egg laying and moths were provided cotton pieces soaked with 10 per cent honey solution for feeding. Paper strips carrying egg masses were collected and transferred to fresh plastic containers and kept in BOD incubator at $27^{\circ} \mathrm{C}$ and 70 per cent RH. On hatching, the larvae were transferred into separate plastic box containing chickpea based artificial diet and fresh food was provided daily in the morning.

\section{Isolation and identification of $P$. fluorescens}

Fluorescent Pseudomonads were isolated from rhizosphere soil of tomato fields from Tamil Nadu, India (Table 1). Isolation of fluorescent pseudomonads was carried out by serial dilution technique using King's B medium (King et al., 1956).

The colonies were examined for morphological characteristics such as shape, size, structure and pigmentation. Presence of fluorescence in UV light was used to select putative $P$. fluorescens colonies.

The individual colonies were picked up with sterile loop and transferred to fresh King's B slants and the pure cultures so obtained were stored in refrigerator at $4^{\circ} \mathrm{C}$ for further use.

\section{In vitro testing of $\boldsymbol{P}$. fluorescens against $\boldsymbol{F}$.} oxysoporum f. sp. lycopersici

All the fifteen of $P$. fluorescens isolates were tested for their antagonistic activity against mycelial growth of $F$. oxysoporum f.sp. lycopersici by following the dual culture technique (Dennis and Webster, 1971). Mycelial disc (8 $\mathrm{mm}$ diameter) of seven days old culture of $F$. oxysoporum f.sp. lycopersici was placed at one side of the Petri plate containing PDA medium at $10 \mathrm{~mm}$ away from the periphery.

Bacterial cultures were streaked onto the medium exactly opposite to the mycelial disc $10 \mathrm{~mm}$ away from the periphery. The plates were incubated at room temperature $(28 \pm$ $2^{\circ} \mathrm{C}$ ) for 10 days. Efficiency of the antagonistic organisms was recorded after seven days on the inhibition zone observed. 


\section{B. bassiana isolates collection, culturing and conidial preparation}

Isolates of $B$. bassiana were obtained from soil using the bait method. Larvae of $H$. armigera and soil samples were collected from different tomato growing regions of Tamil Nadu (Table 2). They were brought back to the laboratory and kept in a refrigerator before use. Each soil sample was placed in four separate plastic Petri dishes, 35 $\mathrm{mm}$ in diameter and a small quantity of sterilized water was added to each dish. Ten bait larvae were placed in each dish and the dishes were kept at room temperature $(28 \pm$ $\left.2^{\circ} \mathrm{C}\right)$. Each larva was removed after $24 \mathrm{~h}$ of burying, transferred to a test tube of $18 \mathrm{~mm} \mathrm{x}$ $180 \mathrm{~mm}$ covered with cheese cloth and fed with a tomato leaf. Larvae were checked daily and cadavers were placed in 35-mm Petri dishes with moistened filter paper after 2-3 days of drying in the tube (Shimazu, 1993). To isolate the B. bassiana, SDAY medium (Sabouraud's dextrose with 1\% yeast extract agar medium) (barley flour $50 \mathrm{~g}$; dextrose 10 $\mathrm{g}$; neopeptone $4 \mathrm{~g}$; yeast extract $2 \mathrm{~g}$; agar 18 $\mathrm{g}$; distilled water $1 \mathrm{~L}$ ) was used. Conidia that formed on the cadavers were streaked onto SDAY. After incubation at room temperature $\left(28 \pm 2^{\circ} \mathrm{C}\right)$ for a week, the colonies obtained were transferred to SDAY slants for further studies. The fungal isolates were identified by microscopically inspecting the conidia forming mycelia for conidiogenous structures and conidial morphology (Samson et al., 1988; Aoki, 1989). B. bassiana isolates were cultured on SDAY medium and the Petri dishes were incubated for 7-10 days at $28 \pm$ $2^{\circ} \mathrm{C}$. The ruling strain of $B$. bassiana, B2 was obtained from the Culture Collection Section, Department of Plant Pathology, TNAU, Coimbatore. The fungal spores were harvested in $25-30 \mathrm{~mL}$ of sterilized distilled water containing $0.05 \%$ Tween 20 (Polyoxyethylene sorbitan monolauriate). The spore count of this stock suspension was estimated with an improved Neubauer haemocytometer. The spore concentration of the suspension was adjusted to $1 \times 10^{8}$ conidia/mL with sterile distilled water and used for the bioassay against $H$. armigera.

\section{In vitro testing of $B$. bassianaagainst $H$. armigera}

Ten $\mathrm{ml}$ of $1 \times 10^{8}$ conidia/ml of each isolates was directly sprayed on the larvae using a hand atomizer. Three replicates of ten larvae were used in each case. Three lots of ten larvae sprayed with $10 \mathrm{ml}$ of sterilized distilled water with 0.05 per cent Tween 20 served as control. The larvae were air dried by keeping them in laminar air flow for five min and carefully transferred to individual clean sterile plastic Petri dish containing fresh leaves. These Petri dishes were then kept inside the BOD incubator at $28 \pm 2{ }^{\circ} \mathrm{C}$. The larval mortality was recorded at $24 \mathrm{~h}$ interval until 10 days of treatment. The per cent larval mortality due to mycosis was calculated and the results of the assay were subjected to probit analysis and the median lethal time $\left(\mathrm{LT}_{50}\right)$ and median lethal concentration $\left(\mathrm{LC}_{50}\right)$ for the virulent isolate were determined.

\section{Compatibility of $P$. fluorescens (TPf12) isolates and B. bassiana (B2) and (TBb8)}

The B2 and TBb8 isolate were taken for further studies based on the higher mortality of $\mathrm{H}$. armigera, inhibition of Fusarium wilt pathogen and molecular characterization. Compatibility of entomopathogenic fungal isolate TBb8 with the best isolate of $P$. fluorescens (TPf12) was tested by following the dual culture technique (Dennis and Webster, 1971). Mycelial disc $(8 \mathrm{~mm}$ diameter) of seven days old culture of $B$. bassiana was placed on the middle of the Petri plate containing equal amount of NA medium and SDY medium and the Pseudomonas was streaked on the medium 
around the mycelial disc. The plates were incubated at room temperature $\left(28 \pm 2{ }^{\circ} \mathrm{C}\right)$ and the compatibility was observed after seven days. Based on the in vitro efficacy of biocontrol agents against $F$. oxysoporum f.sp. lycopersici and $H$. armigera treatments were designed to combat the disease by inducing innate defence mechanism in tomato plants under glasshouse condition.

\section{Native PAGE analysis of systemic resistance inducing enzymes}

\section{Extraction of enzymes}

The leaf tissues or roots were collected from different bioformulation treated and untreated tomato plants and immediately homogenized with liquid nitrogen. One $\mathrm{g}$ of powdered sample was extracted with $2 \mathrm{ml}$ of $0.1 \mathrm{M}$ Sodium phosphate buffer $0.1 \mathrm{M}(\mathrm{pH} 7.0)$ at $4^{\circ} \mathrm{C}$. The homogenate was centrifuged for 20 $\mathrm{min}$ at $10,000 \mathrm{rpm}$. Protein extracts prepared from tomato tissues were used for the assay of phenylalanine ammonia lyase, peroxidase, polyphenol oxidase, and catalase enzymes.

\section{Peroxidase (PO)}

To study the expression pattern of different isoforms of peroxidases in different treatments activity gel electrophoresis was carried out only for Pseudomonas treated plants against Fusarium wilt pathogen. For native anionic polyacrylamide gel electrophoresis, resolving gel of 8 per cent and stacking gel of 4 per cent were prepared. After electrophoresis, the gels were incubated in the solution containing 0.15 per cent benzidine in 6 per cent $\mathrm{NH}_{4} \mathrm{Cl}$ for $30 \mathrm{~min}$ in dark. Then drops of 30 per cent $\mathrm{H}_{2} \mathrm{O}_{2}$ were added with constant shaking till the bands appear. After staining, the gel was washed with distilled water and photographed (Sindhu et al., 1984).

\section{Polyphenol oxidase (PPO)}

Enzyme was extracted by homogenizing one $\mathrm{g}$ of leaf tissue in $0.01 \mathrm{M}$ potassium phosphate buffer $(\mathrm{pH} 7.0)$. The homogenate was centrifuged at $20,000 \mathrm{~g}$ for $15 \mathrm{~min}$. at $4^{\circ} \mathrm{C}$ and the supernatant was used as enzyme source. After native electrophoresis, the gel was equilibrated for $30 \mathrm{~min}$ in 0.1 per cent $p$ phenylene diamine in $0.1 \mathrm{M}$ potassium phosphate buffer ( $\mathrm{pH}$ 7.0) followed by 10 $\mathrm{mM}$ catechol in the same buffer. The addition of catechol was followed by a gentle shaking which resulted in appearance of dark brown discrete bands (Jayaraman et al., 1987).

\section{Catalase}

Electrophoresis was carried out under native condition in 8 per cent polyacrylamide minigels for CAT activity staining. Electrophoresis running conditions were as described by Vitoria et al., (2001) and buffers and gels were prepared as described by Laemmli (1970) lacking SDS. Equal amounts of protein $(40 \mu \mathrm{g})$ were loaded on to each lane. The activity was assayed as described by Woodbury et al., (1971). Gels were incubated in 0.003 per cent $\mathrm{H}_{2} \mathrm{O}_{2}$ for $10 \mathrm{~min}$ and developed in a 1 per cent (w/v) $\mathrm{FeCl}_{3}$ and 1 per cent $(\mathrm{w} / \mathrm{v}) \mathrm{K}_{3} \mathrm{Fe}\left(\mathrm{CN}_{6}\right)$ solution for 10 $\min$.

\section{Superoxide dismutase (SOD)}

Electrophoresis was carried out under native condition in 8 per cent polyacrylamide gels for SOD activity staining.

Electrophoresis running conditions were as described by Vitoria et al., (2001) and buffers and gels were prepared as described by Laemmli (1970) lacking SDS. Equal amounts of protein $(40 \mu \mathrm{g})$ were loaded on to each lane. SOD activity was determined on native PAGE gels as described by Beauchamp and 
Fridovich, (1971). The gels were rinsed in deionized water and incubated in the dark for $30 \mathrm{~min}$ at room temperature in an assay mixture containing $50 \mathrm{mM}$ potassium phosphate buffer ( $\mathrm{pH} 7.8$ ), $1 \mathrm{mM}$ EDTA, 0.05 $\mathrm{m}$ Mriboflavin, $0.1 \mathrm{~m} \mathrm{M}$ nitroblue tetrazolium and 0.3 per cent (v/v) N,N,Ń,Ń-tetramethyl ethylenediamine (TEMED).

At the end of this period, the gels were rinsed with deionized water and placed in deionized water and exposed on a light box for 5 to 10 min at room temperature until the development of colourless bands of SOD activity in a purple-stained gel was visible. The reaction was stopped by transferring the gels to 6 per cent (v/v) acetic acid.

\section{Statistical analysis}

The data obtained were statistically analyzed (Gomez and Gomez, 1984) and the treatment means were compared by Duncan' package used for analysis was IRRISTAT version 92 developed by the International Rice Research Institute, Biometrics Unit, The Philippines.

\section{Results and Discussion}

Efficacy of $\boldsymbol{P}$. fluorescens isolates against $\boldsymbol{F}$. oxysporum f.sp. lycopersici

The fifteen rhizosphere $P$. fluorescens isolates were tested for their efficacy by dual plate technique against $F$. oxysporumf.sp. lycopersici. Among the fifteen isolates, nine isolates were found to be effective against $F$. oxysporum growth in vitro. The $P$. fluorescens isolate TPf 12 showed the highest inhibition of mycelia growth of $F$. oxysporum f.sp. lycopersici followed by TPf 8, TPf 4 and TPf 10. The percent inhibition was significantly higher in plates streaked with TPf12 (50.00\%), TPf8 (44.44\%), TPf4 (40\%), TPf10 (38.88\%) and Pf1 (38.44\%) when compared to control (Table 3).
Pathogenicity of $B$. bassiana against $H$. armigera

The tested isolates of $B$. bassiana showed pathogenicity towards tomato fruit borer $(H$. armigera) with varied mortality rates (Table 4). All the B. bassiana isolates were found pathogenic to larvae of $H$. armigera. Among them TBb8 showed the highest per cent mortality $(93.33 \%)$ followed by B2 $(86.66 \%)$.

Compatibility among $B$. bassiana and $P$. fluorescens

Beauveria bassiana (B2 and $\mathrm{TBb} 8$ ) and $P$. fluorescens (TPf 12) were tested to establish their compatibility under in vitro condition. The results showed that there was no inhibition zone between the B. bassiana (B2 and TBb8) and the bacterial strain (TPf12) indicating the compatibility among the $B$. bassiana (B 2 and TBb8) and bacterial strain, TPf12 (Table 5).

Induction of systemic resistance by bioconsortia of $P$. fluorescens and $B$. bassiana

The activities of the enzymes were estimated and detected in consortia of $P$. fluorescens and $B$. bassiana isolates treated seedlings, which were challenge inoculated with $F$. oxysporum f.sp. lycopersici.

\section{Native PAGE analysis}

\section{Peroxidase (PO)}

The protein samples of seedlings of tomato were analyzed for expression of PO. Native gel electrophoretic separation indicated that entomopathogenic fungal bioformulation treated plants challenge inoculated with $F$. oxysporum f.sp. lycopersici expressed four isoforms $\mathrm{PO} 1, \mathrm{PO} 2, \mathrm{PO} 3$ and $\mathrm{PO} 4$ but in the untreated healthy control plants only two 
isoforms $\mathrm{PO} 3$ and $\mathrm{PO} 4$ were observed. but in the untreated plants only two isoforms Intensity of isoforms was more in the $B . \quad v i z ., \mathrm{PO} 1$ and $\mathrm{PO} 2$ were noticed. In bassiana (TBb8) + P. fluorescens (TPf12) bioformulation B. bassiana $\mathrm{ST}+\mathrm{SD}+\mathrm{SA}$ with treated plants challenge inoculated than TPf12 bioformulation + FS with TBb8 oil untreated control. The induction was observed formulation treated plants, the intensity of up to 9 days thereafter started to decline. isoform banding pattern was high compared Native PAGE analysis in treated plants infested with $H$. armigera showed that there were four isoforms $\mathrm{PO} 1, \mathrm{PO} 2, \mathrm{PO} 3$ and $\mathrm{PO} 4$ to the untreated control but moderate intensity was observed in TBb8 alone and TPf 12 alone treatments (Plate 1).

Plate 1. Induction of peroxidase activity in tomato plants under glass house

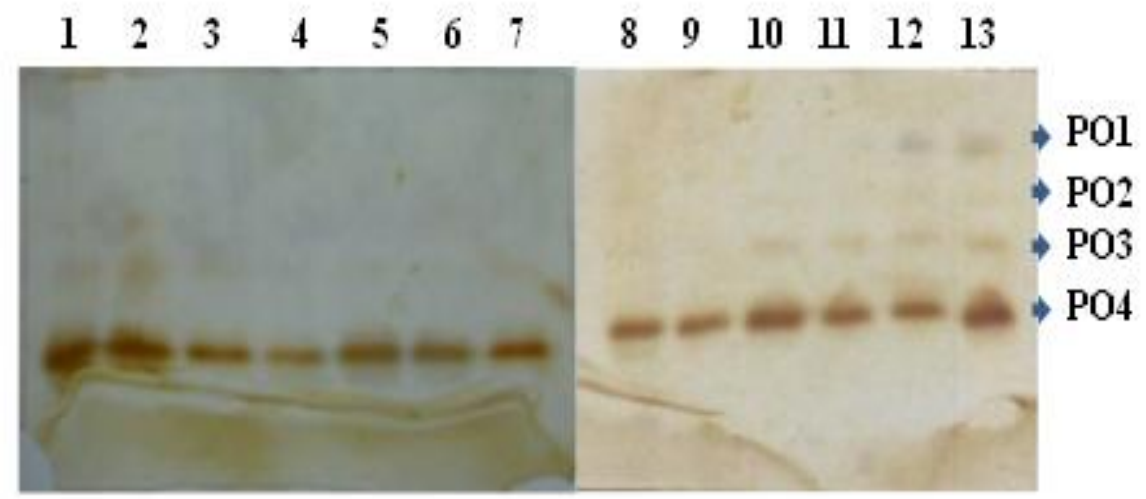

Plate 2. Induction of polyphenol oxidase ac tivity in tomato plants under glass house

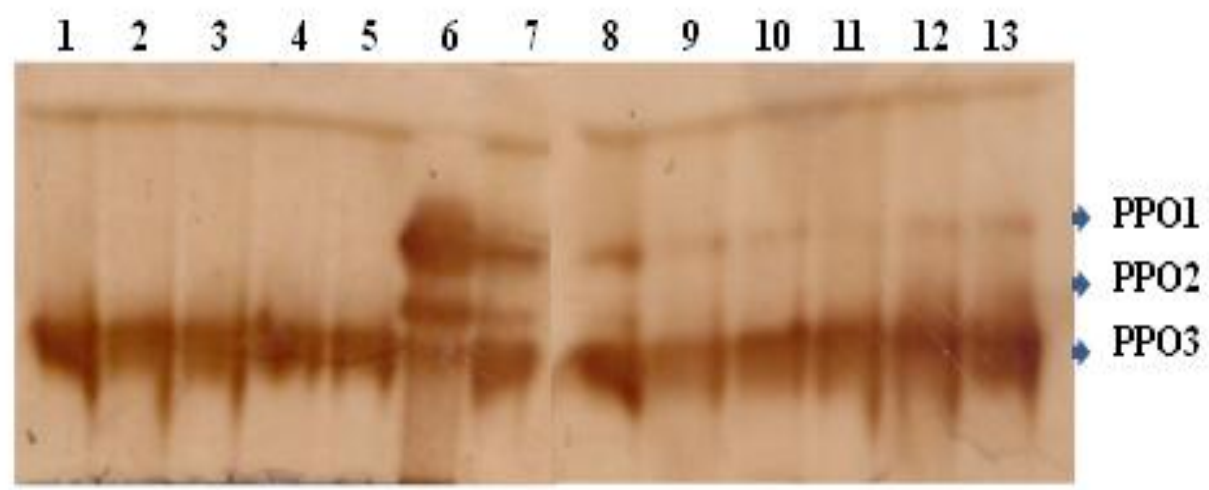


Plate 3. Induction of catalase activity in tomato plants under glass house
$1 \quad 2$
$3 \quad 4$
5
$6 \quad 7$
89
10
11
12
13

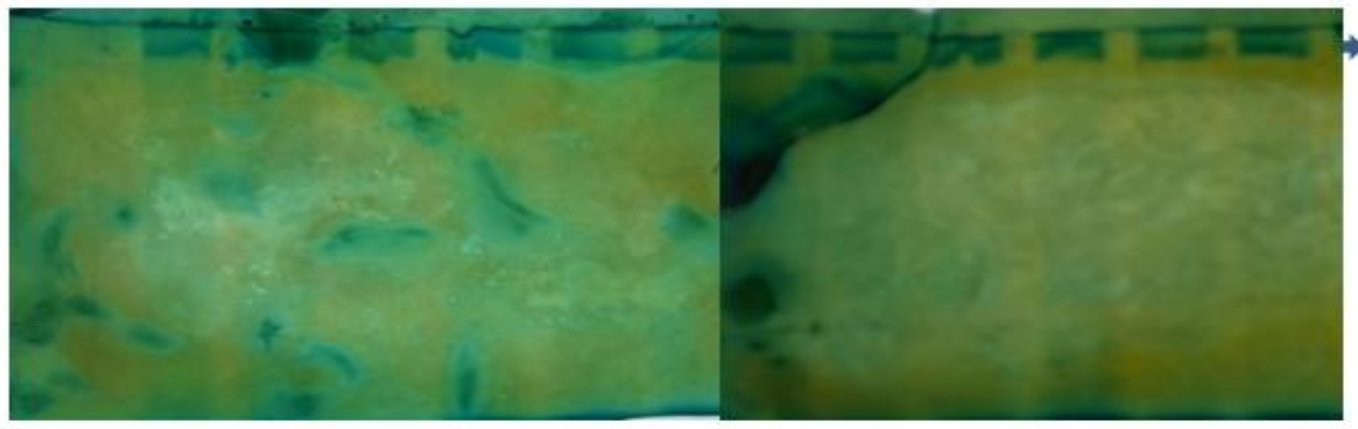

CAT1

Plate 4. Induction of superoxide dismutase activity in tomato plants under glass house

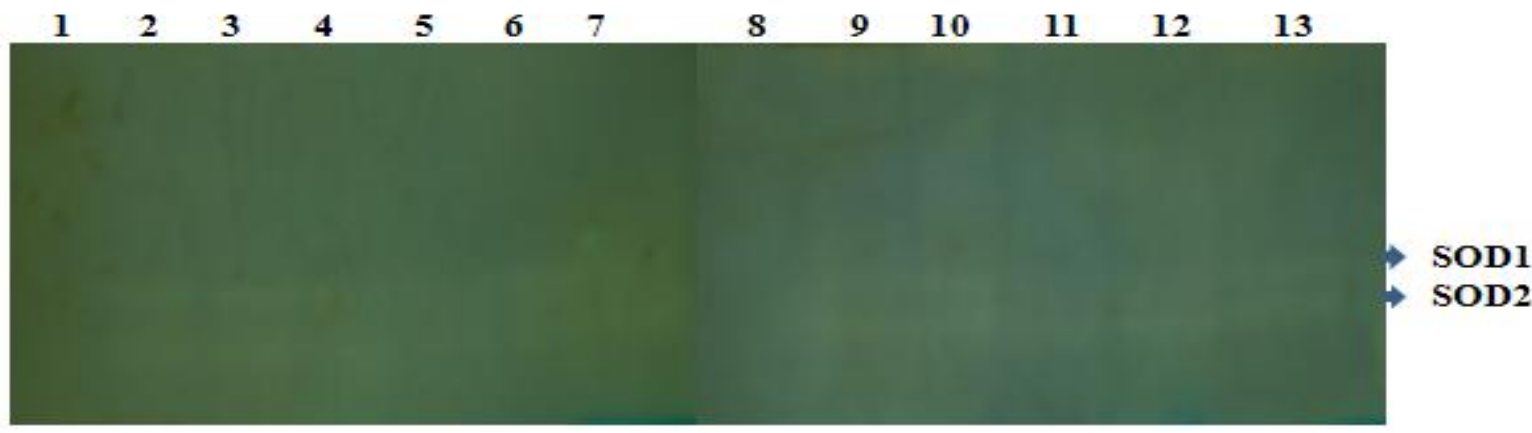

Table.1 Isolation of Pseudomonas fluorescens from different places of Tamil Nadu

\begin{tabular}{|c|c|c|c|}
\hline S.No. & Strains & Place & District \\
\hline 1 & Pf1 & TNAUCampus & Coimbatore \\
\hline 2 & TPf2 & Thazhiyur & Coimbatore \\
\hline 3 & TPf3 & Thondamuthur & Coimbatore \\
\hline 4 & TPf4 & Karamadai & Coimbatore \\
\hline 5 & TPf5 & Malumichampatti & Coimbatore \\
\hline 6 & TPf6 & Pollachi & Coimbatore \\
\hline 7 & TPf7 & Kattukotai & Villupuram \\
\hline 8 & TPf8 & Veerachozhapuram & Villupuram \\
\hline 9 & TPf9 & Kadhuaruthanmedu & Villupuram \\
\hline 10 & TPf10 & Chinnasalam & Villupuram \\
\hline 11 & TPf11 & Kallakurichi & Villupuram \\
\hline 12 & TPf12 & Udumalaipet & Tiruppur \\
\hline 13 & TPf13 & C.K.Valasu & Dindigul \\
\hline 14 & TPf14 & Dindigal & Dindigul \\
\hline 15 & TPf15 & Pudukkottai & Pudukottai \\
\hline
\end{tabular}


Table.2 Isolation of Beauveria bassiana collected from different places of Tamil Nadu

\begin{tabular}{|c|c|c|c|c|}
\hline S.No. & Isolate code & Place & Source & District \\
\hline 1 & TBb1 & Parangipettai & Soil & Cuddalore \\
\hline 2 & $\mathrm{~B} 2$ & TNAUCampus & Infected larva & Coimbatore \\
\hline 3 & $\mathrm{TBb3}$ & Kadhuaruthanmedu & Infected larva & Villupuram \\
\hline 4 & $\mathrm{TBb} 4$ & Chinnasalem & Soil & Villupuram \\
\hline 5 & $\mathrm{TBb5}$ & Veerachozhapuram & Soil & Villupuram \\
\hline 6 & $\mathrm{TBb6}$ & Kallakuruchi & Infected larva & Villupuram \\
\hline 7 & $\mathrm{TBb7}$ & Kattukotai & Soil & Villupuram \\
\hline 8 & $\mathrm{TBb8}$ & Udumalaipet & Infected larva & Tiruppur \\
\hline 9 & $\mathrm{TBb9}$ & Kinathukadavu & Infected larva & Coimbatore \\
\hline 10 & $\mathrm{TBb10}$ & Malumichampatti & Soil & Coimbatore \\
\hline 11 & $\mathrm{TBb11}$ & Thazhiyur & Infected larva & Coimbatore \\
\hline 12 & $\mathrm{TBb12}$ & Pollachi & Infected larva & Coimbatore \\
\hline 13 & $\mathrm{TBb13}$ & Coimbatore & Soil & Coimbatore \\
\hline 14 & $\mathrm{TBb14}$ & Thondamuthur & Infected larva & Coimbatore \\
\hline 15 & $\mathrm{TBb15}$ & Pudukottai & Infected larva & Pudukottai \\
\hline 16 & $\mathrm{TBb} 16$ & C.K.Valasu & Soil & Dindigul \\
\hline 17 & $\mathrm{TBb} 17$ & Dindigul & Infected larva & Dindigul \\
\hline 18 & $\mathrm{TBb} 18$ & Sendhamangalam & Infected larva & Namakkal \\
\hline 19 & $\mathrm{TBb19}$ & Valliyur & Infected larva & Tirunelveli \\
\hline 20 & $\mathrm{TBb} 20$ & Keezhpinnathur & Soil & Tiruvannamalai \\
\hline
\end{tabular}

Table.3 In vitro screening of $P$. fluorescens isolates against $F$. oxysporum f.sp. lycopersici

\begin{tabular}{|c|c|c|c|}
\hline S.No & Isolate & *Mycelial growth of the pathogen $\mathbf{( m m})$ & Per cent inhibition over control \\
\hline 1 & Pf 1 & $55.96(48.10)^{\mathrm{c}}$ & 38.44 \\
\hline 2 & TPf 2 & $64.32(53.46)^{\mathrm{ef}}$ & 30.20 \\
\hline 3 & TPf 3 & $70.90(57.45)^{\mathrm{h}}$ & 21.22 \\
\hline 4 & TPf 4 & $54.00(47.30)^{\mathrm{b}}$ & 40.00 \\
\hline 5 & TPf 5 & $57.00(49.04)^{\mathrm{d}}$ & 36.66 \\
\hline 6 & TPf 6 & $70.00(56.88)^{\mathrm{g}}$ & 22.28 \\
\hline 7 & TPf 7 & $56.40(48.69)^{\mathrm{cd}}$ & 37.33 \\
\hline 8 & TPf 8 & $50.00(45.00)^{\mathrm{ab}}$ & 44.44 \\
\hline 9 & TPf 9 & $68.10(55.64)^{\mathrm{fg}}$ & 24.33 \\
\hline 10 & TPf 10 & $55.00(47.87)^{\mathrm{bc}}$ & 38.88 \\
\hline 11 & TPf 11 & $71.5(56.81)^{\mathrm{h}}$ & 22.22 \\
\hline 12 & TPf 12 & $45.00(42.13)^{\mathrm{a}}$ & 50.00 \\
\hline 13 & TPf 13 & $65.00(53.75)^{\mathrm{fg}}$ & 27.77 \\
\hline 14 & TPf 14 & $63.00(52.55)^{\mathrm{h}}$ & 30.00 \\
\hline 15 & TPf 15 & $60.10(50.78)^{\mathrm{e}}$ & 33.22 \\
\hline 16 & Control & $90.00(71.82)^{\mathrm{k}}$ & - \\
\hline
\end{tabular}


Table.4 Pathogenicity of B. bassiana isolates against $H$. armigera under in vitro conditions

\begin{tabular}{|l|l|c|}
\hline S. No. & Isolate code & *Percentage of larval mortality \\
\hline 1 & TBb1 & $50.00^{\mathrm{hi}}(44.99)$ \\
\hline 2 & B2 & $86.66^{\mathrm{b}}(68.75)$ \\
\hline 3 & TBb3 & $55.33^{\mathrm{fg}}(48.06)$ \\
\hline 4 & TBb4 & $36.66^{\mathrm{i}}(37.26)$ \\
\hline 5 & TBb5 & $73.33^{\mathrm{d}}(58.94)$ \\
\hline 6 & TBb6 & $43.30^{\mathrm{gh}}(41.05)$ \\
\hline 7 & TBb7 & $30.00^{\mathrm{k}}(33.20)$ \\
\hline 8 & TBb8 & $93.33^{\mathrm{a}}(75.74)$ \\
\hline 9 & TBb9 & $40.00^{\mathrm{h}}(39.22)$ \\
\hline 10 & TBb10 & $76.66^{\mathrm{c}}(61.16)$ \\
\hline 11 & TBb11 & $23.33^{\mathrm{kl}}(28.87)$ \\
\hline 12 & TBb12 & $31.66^{\mathrm{j}}(34.24)$ \\
\hline 13 & TBb13 & $46.66^{\mathrm{i}}(43.03)$ \\
\hline 14 & TBb14 & $53.20^{\mathrm{g}}(46.93)$ \\
\hline 15 & TBb15 & $66.66^{\mathrm{e}}(54.75)$ \\
\hline 16 & TBb16 & $40.20^{\mathrm{h}}(39.11)$ \\
\hline 17 & TBb17 & $26.66^{\mathrm{k}}(31.06)$ \\
\hline 18 & TBb18 & $43.38^{\mathrm{j}}(41.11)$ \\
\hline 19 & TBb19 & $51.08^{\mathrm{h}}(44.99)$ \\
\hline 20 & TBb20 & $53.38^{\mathrm{f}}(46.90)$ \\
\hline
\end{tabular}

Values are mean of three replications.

Figures in parentheses represent arcsine transformation.

Means in a column followed by same superscript letters are not significantly different according to DMRT at $\mathrm{P} \leq$ 0.05

Table.5 Treatments based on P. fluorescens (TPf 12) and B. bassiana (TBb 8) bioformulation in tomato under glass house

\begin{tabular}{|c|c|}
\hline \multicolumn{2}{|r|}{ Treatments } \\
\hline $\mathrm{T}_{1}$ & ST with TPf 12 liquid formulation \\
\hline $\mathrm{T}_{2}$ & ST with TBb 8 oil formulation \\
\hline $\mathrm{T}_{3}$ & ST+SD with TPf 12 liquid formulation \\
\hline $\mathrm{T}_{4}$ & $\mathrm{ST}+\mathrm{SD}$ with $\mathrm{TBb} 8$ oil formulation \\
\hline $\mathrm{T}_{5}$ & ST+SD+SA with TPf 12 liquid formulation \\
\hline $\mathrm{T}_{6}$ & $\mathrm{ST}+\mathrm{SD}+\mathrm{SA}$ with $\mathrm{TBb} 8$ oil formulation \\
\hline $\mathrm{T}_{7}$ & $\mathrm{ST}+\mathrm{SD}+\mathrm{SA}$ with TPf 12 liquid formulation $+\mathrm{FS}$ with TBb8 oil formulation \\
\hline $\mathrm{T}_{8}$ & $\mathrm{ST}+\mathrm{SD}+\mathrm{SA}+\mathrm{FS}$ with $\mathrm{TBb} 8$ oil formulation \\
\hline $\mathrm{T}_{9}$ & Seed treatment with Carbendazim @2g/kg of seeds \\
\hline $\mathrm{T}_{10^{-}}$ & Foliar spray with Quinolphos @ 25\%EC \\
\hline $\mathrm{T}_{11^{-}}$ & Inoculated control \\
\hline $\mathrm{T}_{12^{-}}$ & Healthy control \\
\hline $\begin{array}{l}\text { ST- } \\
\text { SD- } \\
\text { SA- } \\
\text { FS - }\end{array}$ & $\begin{array}{l}\text { d treatment }(10 \mathrm{ml} / \mathrm{kg}) \\
\text { edling dip }(1000 \mathrm{ml} / \mathrm{ha} \text { of seedlings }) \\
\text { il application }(1000 \mathrm{ml} / \mathrm{ha}) \\
\text { liar spray }(1000 \mathrm{ml} / \mathrm{ha})\end{array}$ \\
\hline
\end{tabular}




\section{Polyphenol oxidase (PPO)}

Native PAGE analysis of the PPO revealed the induction of four isoforms viz., PPO1, $\mathrm{PPO} 2, \mathrm{PPO} 3$ and PPO4 in the $B$. bassiana (TBb8) and P. fluorescens (TPf12) treated plants challenged with Fusarium wilt in tomato whereas in untreated plants inoculated with Fusarium pathogen only three isoform was observed. Three isoforms viz., PPO1, $\mathrm{PPO} 2$ and PPO3 with high induction of PPO were observed in ST+SD+SA with TPf12 bioformulation + FS with TBb8 oil formulation followed by either TPf12 alone or TBb8 alone treated plants inoculated with $H$. armigera. In control, only two isoform was noticed with lesser intensity.

The extra induction of isoform PPO1 was well pronounced in the $\mathrm{ST}+\mathrm{SD}+\mathrm{SA}$ with TPf12 bioformulation + FS with TBb8 oil formulation followed by either TBb8 alone or TPf12 alone treatments compared to other treatments (Plate 2).

\section{Catalase (CAT)}

Native PAGE analysis of the catalase revealed the induction of two isoforms viz, CAT1 in the B. bassiana (TBb8) and $P$. fluorescens (TPf12) treated plants followed by TPf 12 alone and TBb8 alone treatments challenged with Fusarium wilt in tomato where as in untreated plants inoculated with Fusarium pathogen only one isoform was observed.

More intensity of isoforms was seen from the plants treated with $B$. bassiana and $P$. fluorescens challenged with Helicoverpa pest where in untreated control plants showed isoforms with less intensity. Among the various treatments, $\mathrm{ST}+\mathrm{SD}+\mathrm{SA}$ with TPf12 bioformulation + FS with TBb8 oil formulation treated plants have showed two isoforms with high intensity (Plate 3).

\section{Superoxide dismutase (SOD)}

Native PAGE analysis of the catalase revealed the induction of two isoforms viz., SOD1, SOD2 in the B. bassiana (TBb8) and $P$. fluorescens (TPf12) treated plants followed by TPf 12 alone and TBb8 alone treatments challenged with Fusarium wilt in tomato whereas in untreated plants inoculated with Fusarium pathogen only one isoform was observed. More intensity of isoforms was seen from the plants treated with $B$. bassiana and $P$. fluorescens challenged with Helicoverpa pest where in untreated control plants showed isoforms with less intensity. Among the various treatments, $\mathrm{ST}+\mathrm{SD}+\mathrm{SA}$ with TPf12 bioformulation + FS with TBb8 oil formulation bioformulation has showed two isoforms with high intensity (Plate 4).

The isolates used in this investigation were isolated from tomato rhizospheres as they are well adapted to utilize exudates from their original host plants. The success of plant growth promotion by the rhizobacteria mainly depends on their timely establishment and persistence throughout the growing season at sites where the pathogen may become active. Many of the fluorescent pseudomonads, mainly $P$. fluorescens, have been isolated from suppressive soil mainly for the management of soil borne diseases (Narayanan et al., 2015). Systemic resistance was enhanced in response to fungal and bacterial pathogens challenge in tomato due to high accumulation of defense enzymes (Vanitha et al., 2009). The present work was an effort to analyze the defense related enzyme activity in bacterial wilt pathogenesis of tomato. Infection by pathogens is one of the major stress stimuli that plants often encounter. In response to the infection, the host induces a cascade of pathogen inducible enzymes, which are implemented in defense against phytopathogens. Early and elevated levels of expressions of various defense 
enzymes are an important feature of plant resistance to pathogens. Plants have their own enzymatic resources including PO, PPO, CAT and SOD during host pathogen interactions. Many studies have suggested that PO, PPO, CAT and SOD activities increased plant growth challenged with pathogens (van Loon, 2007). Induced systemic resistance by PGPR fortifies plant cell wall strength and alters host physiology and metabolic responses, leading to an improved production of plant defense chemicals upon pathogen challenge and/or abiotic stress factors (van Loon, 2007). The induced protection by selected strains of PGPR is often associated with the onset of defense mechanisms by expression of various defense related enzymes such as accumulation of phenols and has been shown to promote plant growth (Chitrashree et al., 2011). Investigation of that watermelon plants pretreated with bio agents exhibited higher activity of PO, PPO as well as accumulation of phenol upon challenge inoculation with the pathogen (Umamaheshwari et al., 2009).

Peroxidases are used primarily for the synthesis of secondary metabolites and are known to be induced by various types of stresses including pathogen infection. Peroxidases have been implicated in a number of physiological functions that may contribute to resistance phenol oxidation, lignification and in the deposition of phenolic material into plant cell walls during resistant interaction (Daayf et al., 2007). Both PO and PPO play important roles in biosynthesis of phenolics, phytoalexins and lignin, the three key factors responsible for disease resistance.

Enhanced PO and PPO activity was reported in tomato infected by Fusarium oxysporum (Vanitha et al., 2009). Also our findings support that quick and high induction of PAL and PO was observed in $P$. fluorescens pretreated tomato seedlings, which were inoculated with $F$. oxysporum f.sp. lycopersici.
In the present study, increased activity of PO and PPO was recorded in tomato seedlings grown from seeds treated with $P$. fluorescens after challenge inoculation with the pathogen. In our study, a significant increase in defence enzyme activity till the 24hpi was observed in the $P$. fluorescens treated seedlings challenge inoculated with $F$. oxysporum f.sp. lycopersici indicating the induction of resistance in host plants.

The control seedlings with or without pathogen infection reported the lowest PAL activity without much variation. However, the seedlings inoculated with the $P$. fluorescens isolates alone also exhibited high PAL activity in comparison with the control. Peroxidase catalyzes the last step in the biosynthesis of lignin and other oxidative phenols.

Seed treatment with $P$. fluorescens induced the defense relate activities of PO. Our study reports a significant increase in PO activity at $18 \mathrm{hpi}$, observed in the P. fluorescens treated seedlings challenge inoculated with $F$. oxysporum f.sp. lycopersici indicating the induction of resistance in tomato plants. The control seedlings reported the lowest PO activity with or without pathogen infection with no variation.

However, the seedlings inoculated with the $P$. fluorescens isolates alone also exhibited high PO activity in comparison with the control. Polyphenol oxidase, a copper containing enzyme, oxidizes phenolics to highly toxic quinines and is involved in the terminal oxidation of diseased plant tissue and is attributed for its role in disease resistance. This report also finds the high accumulation of defence related enzymes in plant extracts treated with $P$. fluorescens isolates when compared to the control, the maximum level being attained at $24 \mathrm{hpi}$. The activity of PPO was highest in seedlings pretreated with $P$. fluorescens and later challenge inoculated 
with $F$. oxysporum f.sp. lycopersici. $P$. fluorescens induced resistance against $F$. oxysporum f.sp. lycopersici in tomato seedlings is associated with the enhanced expression of genes for defense related enzymes. Pretreatment of tomato plants with $P$. fluorescens triggered the increased PO, PPO, CAT and SOD activities in response to attack by $F$. oxysporum f.sp. lycopersici.

The present study proves the induction of systemic resistance by $P$. fluorescens against $F$. oxysporum f.sp. lycopersiciin tomato seedlings for defense related enzymes. The application of biocontrol agents as seed treatments could prove to be a beneficial component of integrated pest management. These $P$. fluorescens isolates, apart from their action against bacterial wilt pathogen, are good growth promoters, and are able to induce systemic resistance in tomato plants, which is an added advantage for practical agricultural system. It is evident that rhizobacteria could possibly serve as ecofriendly and sustainable alternatives to the hazardous chemicals used for growth promotion and management of plant diseases.

\section{References}

Abdel-Monaim, M.F.2012.Induced systemic resistance in tomato plants against Fusarium wilt diseases. Inter. Res. J. Microbiol., 3:14-23.

Al-mazaawi, M.S., L.B. Ship, Roadbent and P. Kevan. 2006. Biological control of Lygusline olaris (Hemiptera:Miridae) and Frankliniella occidentalis (Thysanoptera: Thripidae) by Bombus impatiens (Hymenoptera:Apidae) vectored Beauveria bassianain green house sweet pepper. Biol. Control., 37: 89-97.

Beauchamp, C.H. and I. Fridovich. 1971. Superoxide dismutase: Improved assays and an assay applicable to acrylamide gels. Anal. Biochem., 44: 276-287.

Chitrashree, A.C. Udaya Shankar, S.C. Nayaka,
M.S.Reddy and C. Srinivas. 2011. Plant growth-promoting rhizobacteria mediate induced systemic resistance in rice against bacterial leaf blight caused by Xanthomonas oryzae pv.oryzae. Biol. Control., 59:114-122.

Daayf, F., M. Ongena., R. Boulanger, I.El Hadrami and R.R. Belanger. 2000. Induction of phenolic compounds in two cultivars of cucumber by treatment of healthy and powdery mildew-infected plants with extracts of Reynoutria sachalinensis. J. Chem. Ecol., 26: 15791593.

Dennis, C. and J.Webster. 1971. Antagonist properties of species group of Trichoderma. Production of non-volatile antibiotics. Trans. Br. Mycol. Soc., 57: 25-39.

Gomez, K.A. and A.A. Gomez. 1984. Statistical Procedure for Agricultural Research., John Wiley and Sons, New York, USA.

Jayaraman, K.S., M.N. Ramanuja, P.K. Vijayaraghavan and C.S. Vaidyanathan. 1987. Oxidative enzyme in pearl millet. Food Chem., 24: 203.

King, E.O., M.K. Wood and D.E. Raney. 1956. Two simple media for the demonstration of Pyocyanin and Fluorescein. $J$. Lab.Clin.Medi., 44: 301-307.

Kuc, J.1987. Plant immunization and its application for disease control In: Innovative Approaches to Plant Disease Control., John Wiley and Sons, New York. Pg. 255-274.

Laemmli, U.K. 1970. Cleavage of Structural proteins during the assembly of the head of bacteriophage T4.Nature.,227: 680685.

Liu, H., B.L. Skinner and M. Brownbridge. 2002. Pathogenicity of Beauveria bassiana, Metrhaziumanisopliae(Deuteromycotina: Hyphomycetes) and their entomopathogenic fungi against Lygusline olaris (Hemiptera: Miridae). $J$. Econ. Entomol., 95: 675-81.

Nandakumar, R., S. Babu., R.Viswanathan.,T. Raguchander and R. Samiyappan. 2001. Induction of systemic resistance in rice 
against sheath blight disease by Pseudomonas fluorescens. Soil Biol..Biochem., 33: 603-612.

Narayanan, P., S. Vanitha., J. Rajalakshmi., S.Parthasarathy, K. Arunkumar., K. Nagendran, K. and G. Karthikeyan. 2015. Efficacy of bio-control agents and fungicides in management of mulberry wilt caused by Fusarium solani. J. Biol. Cont., 29(2): 107-114.

Narayanan, P., S.Parthasarathy., J. Rajalakshmi., K. Arunkumar and S. Vanitha. 2016. Systemic elicitation of defense related enzymes suppressing Fusarium wilt in mulberry (Morus spp.). African J. Microbiol. Res., 10(22): 813819.

Parthasarathy, S., G. Thiribhuvanamala., K.S. Subramanium. andK. Prabakar. 2016. Bacterial antagonists and hexanal-induced systemic resistance of mango fruits against Lasiodiplodia theobromae causing stem-end rot. J. Plant Interact., 11(1): 158-166.

Parthasarathy, S., J. Rajalakshmi., P. Narayanan., K. Arunkumar and Prabakar K. 2017. Bio-control potential of microbial antagonists against post-harvest diseases of fruit crops: A review. Res Rev J. Bot. Sci., 6(1): 17-23.

Prabhukarthikeyan, R., D. Saravanakumar and T. Raguchander. 2013. Combination of endophytic Bacillus and Beauveria for the management of Fusarium wilt and fruit borer in tomato. Pest Manag. Sci. http://dx.doi.org/10.1002/ps.3719.
Sindhu, J.S., S. Ravi and J.L. Minocha. 1984. Peroxidase isozyme patterns in primary trisomics of pearl millet. Theor. Appl. Genet., 68: 179-182.

Umamaheswari, C., A. Sankaralingam and P. Nallathambi, 2009. Induced systemic resistance in watermelon by biocontrol agents against Alternaria alternata. Arch. Phytopathol. Pl. Protec., 42: 1187-1195.

van Loon, L.C. 2007. Plant responses to plant growth-promoting rhizobacteria. Eur. J. Plant Pathology., 119: 243-254.

van Loon, L.C., C.M.J. Bakker and C.M.J. Pieterse.1998. Systemic resistance induced by rhizosphere bacteria. Annu. Rev.Phytopathol., 36: 453-483.

Vanitha, S. andS. Parthasarathy. 2017. Isolation and characterization of white muscardine fungi Beauveria bassiana (Bals.) Vuill. - A causative of mulberry silkworm. J. Entomol. Zoo. Stud.,5(3): 512-515.

Vanitha, S.C.,S.R. Niranjan, C.N Mortensen, C.N. and S. Umesha, 2009. Bacterial wilt of tomato in Karnataka and its management by Pseudomonas fluorescens. Bio Cont., 54: 685-695.

Vitoria, A.P., P.J. Lea. and R.A. Azevedo. 2001. Antioxidant enzymes responses to cadmium in radish tissues. Phytochem., 57: 710-710.

Woodbury, W., A.K. Spencer. And M.A. Stahmann.1971. An improved procedure using ferri cyanide for detecting catalase iso enzymes. Anal. Biochem, 44: 301-305.

\section{How to cite this article:}

Lakshmidevi, P., S. Parthasarathy, C. Gopalakrishnan, G. Karthikeyan, S. Sridharan and Saraswathi, T. 2017. Expression of Defense Responses in Tomato against Vascular Wilt and Fruit Borer through Consortia of Fluorescent Pseudomonads and Entomopathogenic Fungi. Int.J.Curr.Microbiol.App.Sci. 6(11): 3300-3313. doi: https://doi.org/10.20546/ijcmas.2017.611.387 